\title{
I.UMIRUNC
}

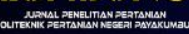

\section{Pengaruh Penambahan Tepung Daun Ubi Kayu Terhadap Berat Telur Dan Ketebalan Kerabang Telur}

\author{
Toni Malvin ${ }^{1}$, Yurni Sari Amir ${ }^{1}$, Muthia Dewi ${ }^{1}$, Salvia $^{1}$ dan Hardiyansa $^{2}$ \\ ${ }^{1}$ Dosen Program Studi Budi Daya Ternak Politeknik Pertanian Negeri Payakumbuh \\ ${ }^{2}$ Mahasiswa Program Studi Budi Daya Ternak Politeknik Pertanian Negeri Payakumbuh \\ Jl. Raya Negara Km. 7 Tanjung Pati, 26271, Payakumbuh \\ Korespondensi:tonimalvin@gmail.com
}

Diterima : 03 Januari 2019

Disetujui : 26 Januari 2019

Diterbitkan : 31 Januari 2019

\begin{abstract}
ABSTRAK
Penelitian ini bertujuan untuk melihat pengaruh penambahan tepung daun singkong (Manihot esculente) ke dalam ransum terhadap berat telur dan tebal cangkang telur. Penelitian ini menggunakan ayam petelur jenis isabrown sebanyak 48 ekor. Perlakuan dalam penelitian ini adalah penambahan daun singkong yang dibuat menjadi tepung dan kemudian ditambahkan ke dalam ransum. R0 merupakan ransum basal tanpa penambahan tepung daun singkong, R1 adalah penambahan 5\% tepung daun singkong ke ransum, R2 adalah penambahan $10 \%$ tepung daun singkong ke ransum dan R3 menambahkan tepung daun singkong $15 \%$ ke dalam ransum. Hasil penelitian memperlihatkan bahwa penambahan tepung daun singkong hingga tingkat $15 \%$ ke dalam ransum, tidak memberikan pengaruh berbeda nyata terhadap berat telur dan tebal kerabang.
\end{abstract}

\section{Keywords: Berat Telur, Daun Ubi Kayu, Ketebalan Kerabang dan Tepung}

\begin{abstract}
This study aims to see the effect(s) of the addition of cassava leaf powder (Manihot esculente) in the ration towards egg weight and eggshell thickness. This study uses 48 Isa brown layer chickens. The treatment in this study is the addition of cassava leave, which were processed into powder, to the ration. Four different types of experiments were conducted. RO utilizes the basal ration without the addition of cassava leaf powder. $R 1, R 2$, and $R 3$ respectively use the dosage of 5,10 , and $15 \%$ of cassava leaf powder in the ration. The results of this study indicate that the addition of cassava leaf powder up to $15 \%$ does not have any significant effect on egg weight and eggshell thickness.
\end{abstract}

Keywords: Egg weight, Cassava leaves, Eggshell Thickness, Flour 


\section{I.UMIRUNC}

\section{PENDAHULUAN}

Kabupaten Lima Puluh Kota merupakan sentra dari peternakan ayam ras petelur di Sumatera Barat. Usaha peternakan ayam petelur ini membuka lahan pekerjaan tersendiri bagi masyarakat, hal ini dapat dilihat dengan adanya peningkatan populasi ayam petelur dari tahun ke tahun. Populasi ayam ras petelur di Kabupaten Lima Puluh Kota pada tahun 2014 berjumlah 4.895.914 ekor dan pada tahun 2015 menjadi 5.061.375 ekor atau mengalami peningkatan 3,38\%. Produksi telur ayam ras pada tahun 2014 berjumlah $37.739 .786,90 \mathrm{~kg}$ dan pada tahun 2015 menjadi 39.023.201,40 kg atau mengalami peningkatan 3,40\%. Sedangkan jika dilihat dari sisi permintaan, konsumsi telur ayam ras pada tahun 2014 sebesar 19.897.380,40 kg dan pada tahun 2015 menjadi 20.501.503,30 atau mengalami peningkatan 3,04\% (BPS Kabupaten Lima Puluh Kota, 2016).

Telur ayam ras sangat digemari oleh masyarakat, karena mengandung nilai gizi yang baik serta harganya relatif murah dibandingkan dengan pangan asal hewani lainnya. Selain untuk dikonsumsi langsung, telur ayam juga banyak digunakan untuk bahan pencampur lainnya, seperti dalam pembuatan kue maupun untuk pengobatan bagi penderita yang kurang nutrisi tertentu. Komposisi gizi telur ayam ras per $100 \mathrm{~g}$ antara lain; air 70,83\%, energi $185 \mathrm{kkal}$, protein 12,81g, lemak 13,77g, karbohidrat 1,45g, mineral 674,36mg, vitamin B6 0,25mg, asam amino $12,99 \mathrm{~g}$, asam pantotenat $1,862 \mathrm{mg}$, riboflavin $0,404 \mathrm{mg}$, tiamin $0,156 \mathrm{mg}$, vitamin $1328 \mathrm{IU}$, niasin $0,20 \mathrm{mg}$, vitamin B12 5,40mcg, vitamin A $674 \mathrm{IU}$ dan kolesterol 884mg (Santoso, 2011). Berdasarkan kandungan gizi ini, telur ayam dapat menjadi salah satu pangan penyumbang kebutuhan nutrisi manusia, sehingga tidaklah heran bila kebutuhan telur akan terus meningkat, apalagi harganya sangat terjangkau oleh kalangan bawah.

Kualitas telur dapat dipengaruhi oleh kualitas ransum yang dikonsumsi oleh unggas petelur. Beberapa faktor yang mempengaruhi besarnya telur adalah sifat genetik, makanan sehari-hari, umur, tingkatan dewasa kelamin dan obat-obatan (Anggorodi, 1995). Perbedaan besar telur yang disebabkan oleh faktor makanan dipengaruhi oleh jumlah protein dan asam amino, serta asam linoleat yang terkandung dalam ransum. Berat telur dan ketebalan kerabang merupakan salah satu indikator dari kualitas telur yang baik. Sekitar 35\% - 75\% kalsium untuk pembentukan kerabang telur berasal dari 


\section{I.UMIRUNC}

konsumsi pakan, sedangkan kalsium yang bersumber dari tulang meduler akan digunakan jika kalsium dari pakan untuk klasifikasi tidak mencukupi (Yuwanta, 2010).

Pemberian pakan ternak yang sesuai dengan kebutuhannya perlu dilakukan agar produk yang dihasilkan baik secara kuantitas dan kualitas. Pada penyediaan bahan pakan hendaklah bahan tersebut mudah didapat, murah harganya, tidak mengandung racun serta memiliki nilai nutrisi yang dibutuhkan. Daun ubi kayu atau dikenal juga dengan nama ketela pohon dan singkong, merupakan salah satu bahan yang dapat digunakan pada ransum ayam petelur karena mengandung nutrisi makro dan mikro yang cukup baik. Zat gizi mikro yang terkandung di dalam daun ubi kayu diantaranya: vitamin A, vitamin B1, vitamin C, kalsium, fosfor, zat besi, seng, kalium, tembaga, magnesium dan mangan. Disamping itu, daun ubi kayu juga memiliki kandungan beta karoten dan asam amino essensial yaitu lisin, leusin, isoleusin, valin dan arginin.

Daun ubi kayu merupakan limbah hasil pertanian dan sangat mudah didapatkan di daerah Sumatera Barat, salah satunya di Kabupaten Lima Puluh Kota, karena daerah ini memiliki banyak UKM kerupuk sanjai yang bahan bakunya adalah ubi kayu. Hasil analisis kimia, tepung daun ubi kayu memiliki kandungan protein kasar $24.32 \%$. Tingginya kandungan protein pada daun ubi kayu ini dapat menjadi salah satu alasan untuk dijadikan sebagai bahan sumber protein dalam penyusunan ransum ayam ras petelur. Penggunaan tepung daun ubi kayu pada puyuh hingga taraf $10 \%$ tidak mengganggu pertumbuhan dan produksi telur serta dapat meningkatkan warna kuning telur (Siregar, 2008). Pemberian tepung daun ubi kayu sampai dengan 6\% pada itik mempengaruhi tingkat konsumsi pakan dan pada taraf 9\% dapat meningkatkan warna kuning telur (Mahardika, 2007).

Berdasarkan latar belakang ini dan mengacu pada hasil penelitian dalam pemanfaatan tepung ubi kayu terhadap puyuh dan itik, maka peneliti tertarik untuk memanfaatkan tepung daun ubi kayu terhadap ayam ras petelur dengan judul "Pengaruh Penambahan Tepung Daun Ubi Kayu Terhadap Berat Telur dan Ketebalan Kerabang Telur". Penelitian ini bertujuan untuk mengetahui persentase penambahan tepung daun ubi kayu dalam ransum terhadap berat telur dan ketebalan kerabang telur ayam ras. 


\section{I.UMIRUNC}

\section{METODE PENELITIAN}

Penelitian ini dilakukan di Farm dan Laboratorium Peternakan Politeknik Pertanian Negeri Payakumbuh. Bahan dan alat yang digunakan berupa ayam ras petelur jenis isa brown berumur 10 bulan, ransum basal ayam ras, tepung daun ubi kayu dan air. Alat yang digunakan terdiri dari kandang dan peralatannya, jangka sorong, timbangan analitik, serta alat tulis. Kandungan nutrisi ransum penelitian dapat dilihat pada Tabel 1. Tabel 1. Kandungan nutrisi ransum

\begin{tabular}{cccccc}
\hline Ransum & PK $(\%)$ & SK $(\%)$ & LK $(\%)$ & Ca $(\%)$ & P $(\%)$ \\
\hline R0 & 15.83 & 5.17 & 5.61 & 1.19 & 0.28 \\
R1 & 15.85 & 6.25 & 5.62 & 1.21 & 0.30 \\
R2 & 15.86 & 7.32 & 5.62 & 1.23 & 0.30 \\
R3 & 15.87 & 8.40 & 5.62 & 1.25 & 0.35 \\
\hline
\end{tabular}

Sumber: Hasil analisa labor kimia Politeknik Pertanian Negeri Payakumbuh (2016)

Rancangan percobaan yang digunakan pada penelitian ini adalah rancangan acak lengkap (RAL) dengan 4 perlakuan dan 4 ulangan. Perlakuan antara lain:

a). $\mathrm{R} 0=$ ransum basal

b). $\mathrm{R} 1=$ ransum basal $+5 \%$ daun ubi kayu

c). $\mathrm{R} 2=$ ransum basal $+10 \%$ daun ubi kayu

d). $\mathrm{R} 3=$ ransum basal $+15 \%$ daun ubi kayu

Parameter yang diamati adalah berat telur dan ketebalan kerabang telur. Berat telur (g) diukur berdasarkan hasil penimbangan telur setiap hari selama pemeliharaan, menggunakan timbangan analitik dengan kepekaan 0,001g. Ketebalan kerabang telur (mm) didapatkan dengan cara mengukur cangkang dan membran telur. Pengukuran tebal kerabang telur dilakukan pada 3 bagian, yaitu ujung tumpul, bagian tengah (ekuator) dan ujung lancip, kemudian dihitung rata-ratanya. Tebal kerabang diukur menggunakan jangka sorong.

Data yang diperoleh dari peubah yang diamati, dianalisis dengan sidik ragam menggunakan SPSS, apabila terdapat perbedaan nyata $(\mathrm{P}<0.05)$ antar perlakuan akan dilanjutkan dengan uji jarak berganda Duncan`s New Multiple Range Test (Steel and Torrie, 1991).

Penelitian ini berawal dengan penyediaan daun ubi kayu hasil limbah pertanian ubi yang dijemur kering dan kemudian dihaluskan untuk dijadikan tepung. Daun yang 


\section{I.UMIRUNC}

digunakan mulai dari pucuk sampai dengan daun tua. Tepung daun ubi kayu ini kemudian dicampurkan atau ditambahkan ke dalam ransum basal dengan persentase yang berbeda. Telur yang didapatkan dari produksi ayam ras ini, diukur berat dan ketebalan kerabangnya.

\section{HASIL DAN PEMBAHASAN}

\section{Berat Telur}

Pengaruh penambahan tepung daun ubi kayu di dalam ransum terhadap berat telur dapat dilihat pada Tabel 2. Berdasarkan hasil analisis ragam pada Tabel 2 diketahui bahwa perlakuan penambahan tepung daun ubi kayu dalam ransum tidak memberikan pengaruh yang berbeda nyata $(\mathrm{P}>0.05)$ terhadap berat telur ayam ras petelur. Didapatkan nilai rataan berat telur dari perlakuan berkisar antara $61,57 \mathrm{~g}$ sampai $63,90 \mathrm{~g}$.

Tabel 2. Rataan berat telur ayam ras petelur selama penelitian (g)

\begin{tabular}{ccc}
\hline No & Perlakuan & Berat Telur $(\mathbf{g})$ \\
\hline 1. & R0 & 62,87 \\
2. & R1 & 61,57 \\
3. & R2 & 63,76 \\
4. & R3 & 63,90 \\
\hline
\end{tabular}

Berbeda tidak nyatanya $(\mathrm{P}>0.05)$ perlakuan penambahan tepung daun ubi kayu terhadap berat telur dikarenakan protein ransum hampir sama, yaitu 15,83 - 15,87 (hasil analisa labor kimia Politeknik Pertanian Negeri Payakumbuh, 2016). Kandungan protein ransum dapat berpengaruh terhadap berat telur. Beberapa faktor yang mempengaruhi besarnya telur adalah sifat genetik, makanan sehari-hari, umur, tingkatan dewasa kelamin dan obat-obatan (Anggorodi, 1995). Faktor makanan yang bisa mempengaruhi besar telur adalah jumlah protein, asam amino dan asam linoleat yang terkandung dalam ransum. Secara umum berat telur dipengaruhi oleh tiga faktor utama yaitu: ternak, pakan, dan lingkungan (Yuwanta, 2010).

Tepung daun ubi kayu dapat digunakan sebagai salah satu bahan pakan penyusun ransum unggas dengan nilai kandungan protein yang bagus yaitu 24,32\%, namun sisi lemahnya, tepung daun ubi kayu memiliki serat kasar yang cukup tinggi. Pada tabel 1 terlihat bahwa semakin besar penggunaan tepung daun ubi kayu, persentase 


\section{I.UMIRUNC}

lemak kasar juga ikut meningkat. Kandungan serat kasar tertinggi terdapat di R3 yaitu $8,40 \%$, sedangkan R0 hanya 5, $17 \%$.

Pada Tabel 2 dapat dilihat bahwa rata-rata berat telur berkisar antara 61,57g sampai 63,90g. Berat telur 61,57g didapatkan dari pemberian ransum dengan penambahan tepung daun ubi kayu 5\% dan berat telur 63,90g didapatkan dari penambahan tepung daun ubi kayu $15 \%$ dalam ransum. Capaian berat telur pada penelitian ini masih dalam batasan berat telur yang normal. Normalnya, berat telur ratarata ayam ras petelur sekitar 57,6g/butir (Rasyaf, 2003).

Secara statistik, penambahan tepung daun ubi dalam ransum tidak memberikan pengaruh yang berbeda nyata terhadap berat telur, namun dari Tabel 2 dapat dilihat bahwa penambahan $15 \%$ tepung daun ubi kayu (R3) menghasilkan rataan berat telur yang lebih tinggi dari telur yang lain. Hal ini dikarenakan penambahan $15 \%$ tepung daun ubi kayu dapat sedikit meningkatkan nilai nutrisi dari ransum, protein menjadi $15,87 \%$, calsium $1,25 \%$ dan fosfor $0,35 \%$.

\section{Ketebalan Kerabang Telur}

Pengaruh penambahan tepung daun ubi kayu di dalam ransum terhadap ketebalan kerabang telur selama penelitian dapat dilihat pada Tabel 3. Berdasarkan hasil analisis ragam diketahui bahwa perlakuan penambahan tepung daun ubi kayu dalam ransum tidak memberikan pengaruh yang berbeda nyata $(\mathrm{P}>0,05)$ terhadap ketebalan kerabang telur ayam ras petelur.

Tabel 3. Rataan ketebalan kerabang telur ayam ras petelur selama penelitian (mm).

\begin{tabular}{ccc}
\hline No & Perlakuan & Ketebalan Kerabang Telur $(\mathrm{mm})$ \\
\hline 1. & R0 & 0.53 \\
2. & R1 & 0.50 \\
3. & R2 & 0.54 \\
4. & R3 & 0.53 \\
\hline
\end{tabular}

Ketebalan kerabang telur berkisar antara 0,50 mm sampai dengan 0,54 mm. Tidak adanya pengaruh yang berbeda nyata $(\mathrm{P}>0,05)$ pada penambahan tepung daun ubi kayu terhadap ketebalan kerabang, dikarenakan penggunaan tepung daun ubi kayu dengan setiap peningkatan level 5\% tidak terlalu berpengaruh terhadap peningkatan kandungan kalsium pada ransum seperti yang terlihat pada Tabel 1. Perbedaan 


\section{I.UMIRUNC}

kandungan kalsium ransum kontrol (R0) dengan ransum yang diberi 5\% (R1), 10\% (R2) dan $15 \%$ (R3) tepung daun ubi kayu secara berurutan adalah $0,02 \%, 0,04 \%$ dan $0,06 \%$. Berdasarkan data tersebut, terlihat bahwa setiap penambahan 5\% tepung daun ubi kayu ke dalam ransum hanya meningkatkan kandungan kalsium sebesar 0,02\%.

Ketebalan kerabang telur merupakan salah satu variabel yang menentukan kualitas telur. Kerabang telur sebagian besar dibentuk dari kalsium karbonat (CaCO3). Sumber Ca dapat berasal dari pakan dan tulang meduler. Sekitar 35\%-75\% kalsium untuk pembentukan kerabang telur berasal dari pakan, sedangkan kalsium yang bersumber dari tulang meduler akan digunakan jika kalsium dari pakan untuk kalsifikasi tidak mencukupi (Yuwanta, 2010). Apabila konsumsi pakan menurun, maka intake kalsium yang digunakan untuk pembentukan kerabang telur menjadi sedikit, hal ini akan mempengaruhi ketebalan kerabang dan berdampak pada kualitas kerabang seperti kerabang tipis ataupun kerabang lembek. Konsumsi kalsium yang semakin tinggi akan menghasilkan kualitas kerabang telur menjadi semakin baik (Clunies dkk, 1992). Ternak unggas yang diberi ransum mengandung kalsium tinggi, cenderung akan menghasilkan kerabang telur yang tebal, sehingga akan berpengaruh kepada berat kerabang (Sarwono, 1994).

Kerabang telur terbentuk dari 4 bagian, yaitu: a) kutikula, merupakan lapisan yang sangat tipis (3-10 mikron) dan tidak memiliki pori-pori, namun masih dapat dilalui gas; b) lapisan bunga karang (spongy/calcareous layer), berupa lapisan kapur ( $\mathrm{CaCO} 3$; $\mathrm{Ca}(\mathrm{PO} 4) 2, \mathrm{MgCO} 3, \mathrm{Mg} 3(\mathrm{PO} 4) 2$ yang berbentuk anyaman dan terdiri dari protein serabut; c) lapisan mamalia (mammilary layer), merupakan lapisan yang sangat tipis, tebalnya 1/3 lapisan seluruh kerabang telur; d) lapisan membran, tebalnya sekitar 65 mikron dan terdiri dari 2 lapisan yang menyelubungi seluruh telur, dimana semakin ke bagian yang tumpul, lapisannya akan semakin tebal (Kurtini et al., 2011).

Pada Tabel 3 terlihat ketebalan kerabang telur berkisar 0,50 mm sampai dengan 0,54 $\mathrm{mm}$. Idealnya, tebal kerabang telur ayam berkisar antara 0,33 - 0,36 $\mathrm{mm}$ (Idris dan Thohari, 1998). Tebalnya kerabang telur pada penelitian ini disebabkan karena ayam yang digunakan masih berumur muda. Tebalnya kerabang telur dipengaruhi oleh beberapa faktor yaitu: komponen lapisan kerabang telur, tipe ayam, umur, zat-zat makanan, stres dan peristiwa faal dari organ tubuh. Ketebalan kerabang juga 


\section{I.UMIRUNC}

dipengaruhi oleh faktor yang berhubungan dengan sifat genetik, kalsium dalam pakan, dan manajemen seperti temperatur lingkungan, stress, penyakit, dan pakan (Oguntunji dan Alabi, 2010).

\section{KESIMPULAN}

Berdasarkan hasil dan pembahasan dapat diambil kesimpulan bahwa penambahan tepung daun ubi kayu dalam ransum ayam petelur sampai dengan batas $15 \%$ tidak memberikan pengaruh yang berbeda nyata terhadap berat telur dan ketebalan kerabang telur.

\section{REFERENSI}

Anggorodi, R. 1995. Nutrisi Aneka Ternak Unggas. Gramedia Pustaka Utama, Jakarta.

BPS Kabupaten Lima Puluh Kota, 2016. Kabupaten Lima Puluh Kota Dalam Angka 2016. ISSN: 0215-3742, Katalog: 1102001.1308. BPS Kabupaten Lima Puluh Kota.

Clunies. M., D. Parks and S. Lesson, 1992. Calcium and phosphorus metabolism and egg Shell formation of hens fed different amounts of calcium. Poultry Science 71:482-489.

Dinas Peternakan Kabupaten Lima Puluh Kota. 2010. Kegiatan Pendaatan Masalah Peternakan Program Pencegahan dan Penanggulangan Penyakit Ternak tahun Anggaran 2010. Payakumbuh.

Idris, S dan I. Thohari. 1998. Telur dan Cara Pengawetannya. Fakultas Peternakan. Universitas Brawijaya. Malang.

Kurtini, T., K. Nova, dan D. Septinova. 2011. Produksi Ternak Unggas. Universitas Lampung. Bandar Lampung.

Mahardika G. 2007. Perubahan warna kuning telur itik lokal dengan penambahan tepung kaliandra (Calliandra calothyrsus) dan tepung daun singkong (Manihot esculenta Crantz) pada pakan [skripsi]. Bogor (ID). Institut Pertanian Bogor.

Oguntunji, A.O. and O.M. Alabi. 2010. Influence of high environmental temperature on egg production and shell quality: a review. World's Poultry Science Journal. 66: 739-750.

Rasyaf, M. 2003. Beternak Ayam Petelur. Penebar Swadaya, Jakarta. 


\section{I.UMIBUNG}

Santoso, U. 2011. Telur Ayam Ras, Telur Puyuh dan Telur Ayam, Mana yang Lebih Baik? http://livestock-livestock.blogspot.co.id/2011/10telur-ayamras-telur-puyuhdan-telur-ayam.html. Didownload tanggal 15 Juni 2017 jam 17.00 WIB.

Sarwono, B. 1994. Pengawetan Telur Dan Manfaatnya. PT. Penebar Swadaya, Jakarta.

Siregar B. 2008. Pengaruh penambahan tepung daun singkong (Manihot utilisima crantz) dalam pakan terhadap performans produksi telur puyuh (Cortunix cortunix japonica) petelur. Jurnal Ilmiah Ilmu-Ilmu Peternakan Vol 11(1):28-33.

Steel, R.G.D. dan J.H. Torrie, 1991. Prinsip Prosedur Statistika. Gramedia Pustaka Utama, Jakarta.

Yuwanta, T. 2010. Telur dan Kualitas Telur. UGM Press, Yogyakarta. 